\title{
A Taphonomic Examination of Inhumed and Entombed Remains in Parma Cemeteries, Italy
}

\author{
Edda Guareschi, Ian R Dadour and Paola A Magni* \\ Medical, Molecular \& Forensic Sciences, Murdoch University, Australia
}

*Corresponding author: Paola A Magni, Medical, Molecular \& Forensic Sciences, Murdoch University, 90 South Street, Murdoch, Western Australia.
Received Date: April 15, 2019

Published Date: May 23, 2019

\begin{abstract}
People of different cultures bury their dead in different ways, based on religious beliefs, historical rituals, or public health requirements. In Italy, cremation is still a limited practice compared to entombment and inhumation. Accordingly with the law, a buried body can be moved to the cemetery ossuary only if skeletonized. Generally, complete skeletonization occurs within 40 years following burial, but sometimes the body may mummify, or it may turn into adipocere. Globally, today burial space is limited with cemeteries facing a growing need for both burials and entombments. The present study considered the thanatological, taphonomical, anthropological, microbiological and geochemical examination of 408 human bodies exhumed from grave pits and stone tombs located in two cemeteries in Parma, Italy. Intrinsic and extrinsic factors associated with the process of the decomposition of such bodies were documented in order to identify which factors promote or reduce the time needed for skeletonization. Overall, the aim of this study was to improve the management of the body turnover in cemeteries, providing recommendations for cemetery management and turnover planning, with the goal of avoiding extra costs that may be attributed to the family and the State. The results of this study show that inhumation in burial grounds and soils with a high percentage of sand and gravel promote decomposition and skeletonization, whereas entombments inside stone tombs and the presence of stone slabs on the ground covering burials, aid in the formation of adipocere, slowing down the decomposition process.
\end{abstract}

Keywords: Inhumation; Entombment; Forensic taphonomy; Adipocere

\section{Introduction}

Around the world, burial practices are promoted in the attempt to demonstrate respect for the dead, to bring closure to the deceased's family, to help reaching the afterlife, to return the remains to the cycle of life or to preserve the body for future use. In an attempt to do this, people of different cultures bury their dead in many alternate ways, in accordance with religious beliefs, historical rituals, or public health requirements [1]. In general, human remains are a) buried in the earth to decompose naturally (natural burials e.g. memorial reefs, mushroom burials, tree pod burials, resomation); b) be preserved for the years to come (e.g. mummification, embalming, inhumation, entombment, cryonics); c) to skip the decomposition process completely (e.g. cremation). As well, some people donate their bodies to science, and such remains may be preserved for anatomical studies in Universities or for decomposition studies at anthropology research facilities [2]. In Italy, within the 15384 cemeteries present in the country, and according to a 2007 survey, the percentage of entombments and inhumations were $58 \%$ and $32 \%$ respectively, while cremation was only $10 \%$, compared to the European average of $36 \%$ [3].

From 2014 to 2018, the choice of cremation in Italy has increased from $19,71 \%$ to $23 \%$, while the European average remains around $38 \%[4,5]$. Today, many countries are facing the problem of cities running out of space to bury their dead, and several solutions have been considered (e.g. relocation of the bodies, multi-story burial space, green burials) [6,7]. In Italian cemeteries, exhumations are performed throughout the year to maximize the shortage of space in existing cemeteries. According to the present law (Regolamento di Polizia Mortuaria [8]) inhumations and entombments are subjected to an exhumation turnover at 10, 20 or 40 years, depending on the circumstances of the specific case (e.g. following a request by the family or at the prosecutor's discretion in a forensic investigation). Until the second half of the last century, human remains exhumed after such periods were generally completely skeletonized, and bones were collected and secured in the cemetery ossuary. In 
recent times, due to the use of modern types of coffins, the natural decomposition process has slowed down.

As a consequence, after the planned turnover time, the remains are often still in an advanced stage of decay. In such cases, the family of the deceased that is not skeletonized will have to choose between cremation or re-inhumation of the remains. Costs can be significant. If there is no family or if the family is not able to afford it, then the cost for re-inhumation or cremation of the remains will be covered by local government. In such cases, the family will sign a disinterest document and will not be notified about the body's treatment or future location. According to the Italian Regolamento, only coffins can be used for inhumation or entombment of human remains [8]. The Regolamento also states that bodies destined for transport and entombment must be placed in two coffins, the inside one made of metal (usually zinc), and the external coffin is typically made of wood with metal edges where the top and the bottom part seal [8]. The outer part of the coffin is then sealed via welding.

When a body is transported during the warm seasons, an anti-putrefactive treatment with formaldehyde is applied to the remains, another factor that will retard decomposition. Regarding entombment, the tomb must be watertight and airtight, which is usually achieved using bricks and mortar. Inhumation pits must be at least $2 \mathrm{~m}$ deep and at least $0.50 \mathrm{~m}$ from other pits. Pathways between pits must be equipped with water draining systems. When a secondary inhumation is required, the zinc coffin - if present can be removed to facilitate the skeletonization process. As an alternative, if the zinc coffin is not removed, the metal must be breached for the same purpose. The Regolamento does not specify the number or the size of these breaches, but such breaches are simply made using the tip of the shovel during the process of the re-inhumation. A total of 5-15 breaches are commonly made with each breach being of an opening of approximately $15 \times 3 \mathrm{~cm}$.

The present study considered the biological and taphonomical analyses of 408 human bodies exhumed from two cemeteries located in Parma, Italy. Subjects were deceased between 1920 and 1989 and were exhumed from grave pits (338 individuals) and stone tombs (70 individuals). In these two cemeteries, the turnover time is 20 years for exhumation from grave pits, and 40 years for exhumations from stone tombs. All 408 bodies were assessed on their decomposition status which included intrinsic factors (factors related to the nature of the body itself) and extrinsic factors (factors related to the environment in which the decomposition process occurred).

The present study provides the first set of data attempting to understand the variables influencing decomposition in cemeteries and identifies the geochemical and anthropological variables responsible for the different decomposition processes in the Parma environment. Results of this study will help improve the management of the body turnover in city cemeteries and provide some fundamental information on how to plan cemeteries for the future, based on the nature of the burial environment. A correct protocol for when cemeteries should be turned over will translate into relevant savings for public and private finances. More significantly, families may be able to avoid any distress caused by post-exhumation decisions.

\section{Materials and Methods}

This study considered the anthropological, taphonomical and microbiological analyses of 408 human bodies exhumed from two cemeteries located in Parma, Italy. Bodies from cemetery "La Villetta" $\left(44^{\circ} 79^{\prime} 00^{\prime \prime} \mathrm{N} 10^{\circ} 31^{\prime} 43^{\prime \prime} \mathrm{W}\right)$ were exhumed from coffins buried in separate grave pits located in a green area labelled D5 (Figures

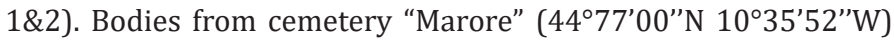
were recovered from coffins individually placed in stone tombs (Figures 1\&2). The exhumations of the bodies took place between April-May 2008 and October-November 2008, respectively. All buried bodies were exhumed using the typical archaeological excavation procedure [9]. An ad hoc spreadsheet was produced to describe and assess the remains. Prior to the exhumation, the families of the deceased were notified of the procedure, as it was within their rights to attend. In regard to cemetery "La Villetta", beside the analyses of the human remains, a geotechnical analysis of the burial ground was performed. Results of the anthropological and geotechnical analyses of D5 were compared with the results of a similar assessment performed in 2007 on 384 bodies exhumed from other green areas of the same cemetery, marked as D3 (188 bodies) and D6 (196 bodies). In these areas the lawn was partially covered with stone slabs, whereas area D5 was only lawn.

\section{Assessment}

Following exhumation, the bodies were examined using forensic pathology and taphonomy practices [10,11]. Each body was categorized as total skeletonization, partial skeletonization, mummification or corification/adipocere [12]. Of the many possible taphonomical assessments available in the present literature $[11,13]$, this study deferred to the model of Carlson and Steele (1992), and considered four variables:

1. The object of the analyses, e.g. full/partial remains at different stages of decomposition [14,15].

2. Location of the disposal, e.g. soil surface or burial.

3. Physical or biological factors affecting the decomposition process, e.g. temperature, humidity, bacterial activity.

4. Cultural factors e.g. cause of death, corpse transport, embalment.

Furthermore, this study considered the following intrinsic and extrinsic factors that may have affected the decomposition process:

a) Personal information: age at death, drug treatments during life, cause of death, if known, and considering the Italian and European privacy policy $[16,17]$,

b) Location of the burials and the tombs within the cemeteries.

c) Depth of the burial pit. 
d) Type and characteristics of the burial ground, via geotechnical analyses.

e) Type of coffin: construction material, structure (simple or double), type of sealing.

f) Garments and upholsteries classified into natural fibers (e.g. cotton, wool and linen) and synthetic fibers.

g) Presence of artifacts such as prosthesis and dentures.

\section{Microbiological analyses}

Biological specimens were collected only from bodies exhumed from stone tombs, as the majority of the inhumed bodies were completely skeletonized. From five random bodies entombed in 1964, 1965, 1967 and 1989, a sample of soft tissue $(10 \times 5 \times 3 \mathrm{~cm}$ of skin, fat and muscle of a limb) was collected for microbiological analyses. Microbiological analyses were performed in order to determine if there was any difference in microbial populations within bodies entombed for different periods of time. Each sample was analyzed as follows:

1) Microscopic examination with Gram staining.

2) Tissue culture, after tryptose broth enrichment in $\mathrm{CO}_{2}$ at 37 ${ }^{\circ} \mathrm{C}$

3) Tissue culture in anaerobiosis at $37^{\circ} \mathrm{C}$.

4) Tissue culture for the presence of molds and yeasts at $25^{\circ} \mathrm{C}$ and $37^{\circ} \mathrm{C}$

API® (Analytical Profile Index) 20E BioMérieux was used as a biochemical panel for the identification and the differentiation of the microorganisms.

\section{Statistical analyses}

Data obtained from the 2 cemeteries were analyzed by multivariate analyses associated with contingency tables taking into consideration the type of burials (grave pit and stone tombs), the intrinsic and extrinsic variables (type and number of coffins, burial time, decomposition status, presence of garments, upholsteries and body artefacts) and the number of bodies. These were considered as percentage categories $(0-10 \%, 10-30 \%$, $30-60 \%, 60-90 \%, 90-100 \%$ ) The effect of the type of soil (soil composition and permeability) was considered only for the grave pits and compared with the information from the geochemical assessment performed in 2007. The effect of the microbiome on the decomposition process was only considered for the stone tombs. The level of significance was set at $\mathrm{P}<0.05$. Calculations were performed using IBM SPSS Statistics 22 statistical software package. The effect of personal information (e.g. age at death, cause of death, ante mortem diseases), conservative body treatments, and secondary inhumation/entombments (for the stone tombs) were not considered in this study as such information were too vague or incomplete to perform a robust statistical analysis.

\section{Results}

\section{Grave Pits}

Cemetery "La Villetta"- A total of 338 bodies deceased between 1920 and 1989 were recovered from coffins buried in individual grave pits in D5 area (Figures 1-3). The cemetery file archive detailed that $73(21.60 \%)$ of the total number of exhumed bodies were secondary inhumations. These bodies where deceased before 1987, and the inspection at the time of the first exhumation revealed that the remains lacked enough decomposition to be transferred to the ossuary. At the end of the present exhumation, only 5 (1.50\%) of the 338 exhumed bodies required reburial or cremation, because of the lack of decomposition. Four of these bodies were reburied in 1988 and one in 1989. For these 5 bodies, the secondary inhumation had no effect on the skeletonization process $(\mathrm{P}>0.05)$. In comparison, of the 384 bodies exhumed from D3 and D6 area, an higher percentage required secondary inhumation or cremation (14.84\%, N=157). In particular, 53 bodies in D3 (28.20\%, of the 188 bodies in total) and 104 bodies in D6 (53.10\% of the 196 bodies in total). The decomposition pattern was found to be statistically different between the D5 and D3-D6 areas $(\mathrm{P}<0.05)$.

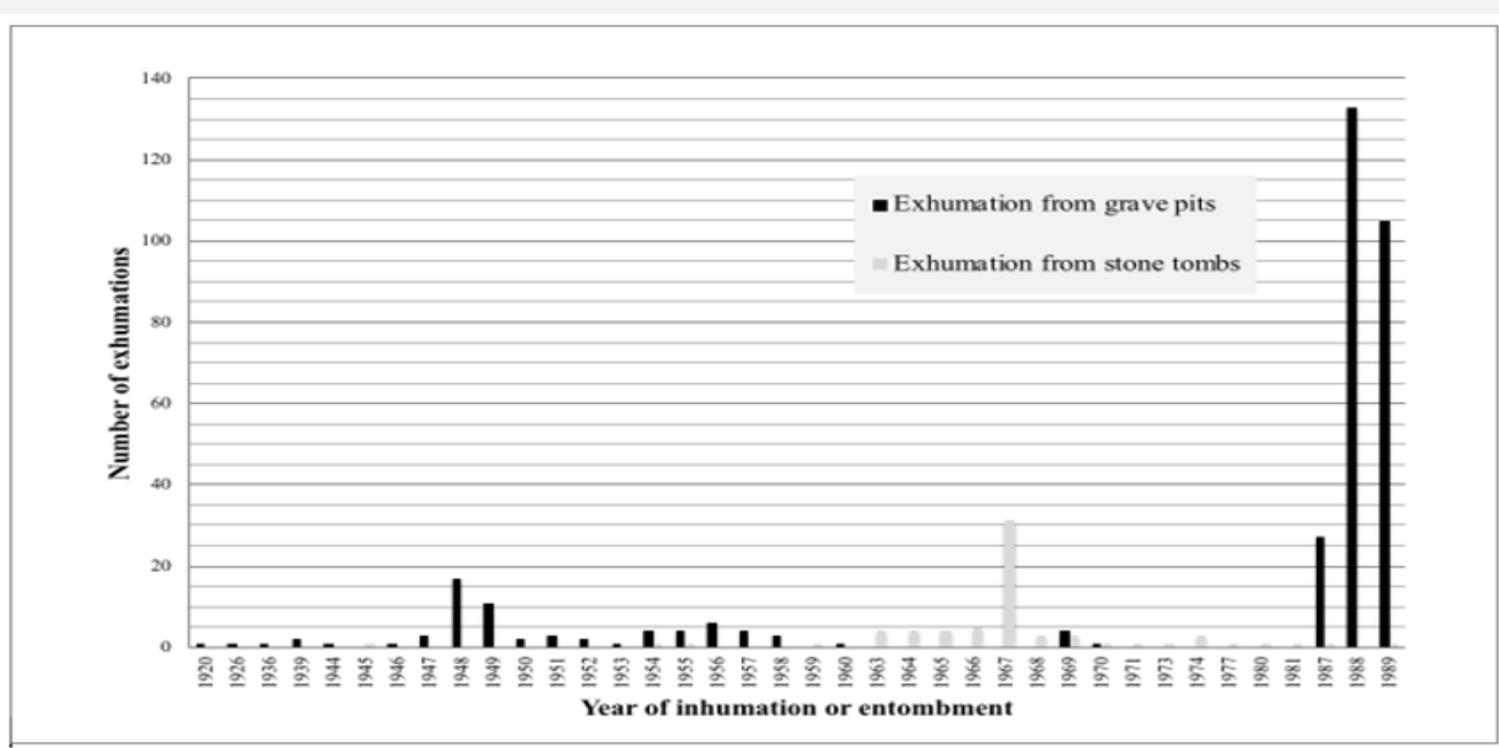

Figure 1: Number of bodies exhumed from grave pits and stone tombs, considering the year of the first burial (inhumation or entombment). 

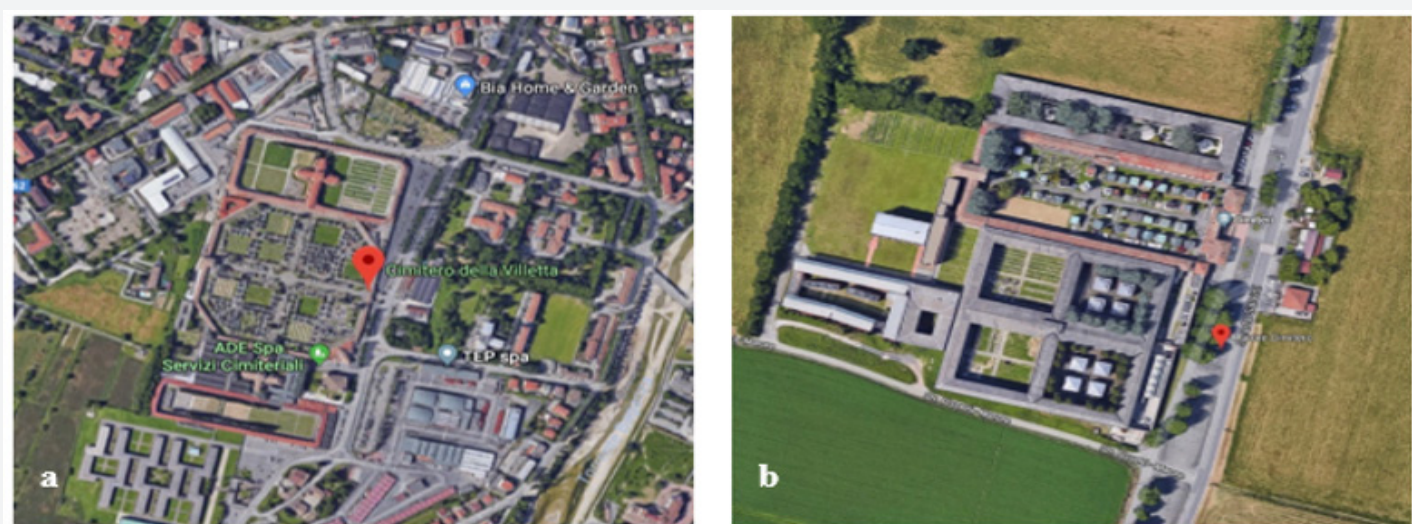

Figure 2: Location of cemetery "La Villetta" and cemetery "Marore”, Parma (Italy), from Google maps.
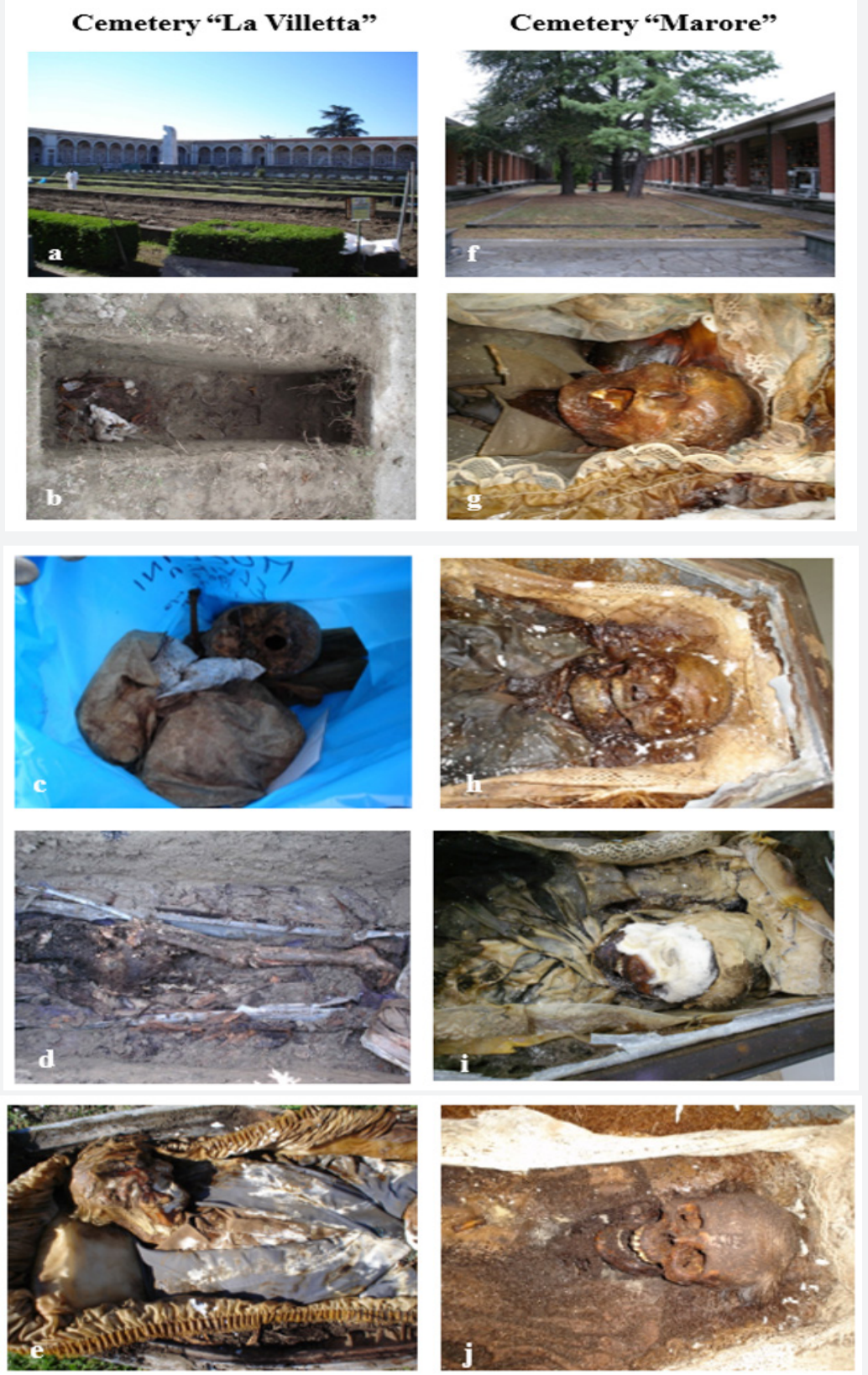

Figure 3: Cemetery "La Villetta": a) D5 burial area; b) typical grave pit in D5 area; c) human remains completely skeletonized, ready to be moved to the cemetery ossuary; d) human remains partially turned into adipocere; e) human remains completely tuned into adipocere. Cemetery "Marore": f) location of the stone tombs object of this study; g) human remains that show external corification with internal adipocere; h) human remains partially turned into adipocere; i) human remains partially covered by mould; j) human remains in complete skeletonization. 


\section{Personal information}

The majority of the bodies belonged to adults (99.82\%, $\mathrm{N}=334$ ), the four remaining were juveniles, between 10 and 18 years of age. The causes of death were mostly natural, while a few were reported as violent (drowning, car accident, suicide). In case of natural death by cancer, the average duration of radio- and/or chemotherapy was reported to be about one year before death, according to information given by relatives present to the exhumation. Only 17 individuals (5.03\%) showed signs of an autopsy, with cranial and thoracic autopsy cuts.

\section{Location and depth of the burial}

The coffins located in the D5 area were buried in grave pits covered by green lawn measuring approximately $1000 \mathrm{~m}^{2}$, under full sun exposure (Figure 2), and no stone slabs were placed over any grave. The depth of each burial pit ranged between $1.8 \mathrm{~m}$ to $2 \mathrm{~m}$.

Table 1: Results of the geotechnical analyses performed in the different area of cemetery "La Villetta". The numbers report the minimum and maximum values obtained from the analyses of a total of 4 samples (D3 and D6) and 4 samples (D5).

\begin{tabular}{|c|c|c|}
\hline \multicolumn{3}{|c|}{ Cemetery “La Villetta” } \\
\hline Cemetery area & D3 and D6 & D5 \\
\hline Year of geotechnical analyses & 2007 & 2008 \\
\hline Depth (m) & $0-1.40$ & $0.35-2.25$ \\
\hline R.U. \% & $17.00-23.10$ & $40.40-77.30$ \\
\hline Saturation \% & $90.05-91.30$ & $68.90-98.10$ \\
\hline Empty Index & $0.63-0.68$ & $0.56-0.84$ \\
\hline Aerobic bacteria (UFC/g) & $240000-280000$ & $1800000-3800000$ \\
\hline Anaerobic bacteria (UFC/g) & $8000-72000$ & $100000-200000$ \\
\hline Total $\mathrm{N}_{2}(\% \mathrm{w} / \mathrm{w})$ & $0.10-0.14$ & $0.11-0.13$ \\
\hline Total Organic Carbon (TOC) (\%) & $0.37-0.90$ & $0.65-0.80$ \\
\hline Available phosphorus (mg/kg) & $150-155$ & $98-130$ \\
\hline $\mathrm{C}_{2} / \mathrm{N}_{2}$ & $3.6-6.3$ & $\mathrm{~N} / \mathrm{A}$ \\
\hline $\mathrm{O}_{2} \%$ & $\mathrm{~N} / \mathrm{A}$ & $7.50-15.10$ \\
\hline Potassium mg/Kg & $\mathrm{N} / \mathrm{A}$ & $1680-1720$ \\
\hline Water content \% & $21.20-23.10$ & $19.00-24.80$ \\
\hline $\mathrm{pH}$ & $\mathrm{N} / \mathrm{A}$ & $7.33-7.97$ \\
\hline Cationic Exchange (CSC) meq/100g T.F. & $\mathrm{N} / \mathrm{A}$ & $19.50-20.30$ \\
\hline Gravel (\%) & $12.60-15.30$ & $0.30-7.80$ \\
\hline Sand (\%) & $34.60-44.80$ & $14.20-50.10$ \\
\hline Loam (\%) & $28.30-33.30$ & $33.00-59.90$ \\
\hline Clay (\%) & $14.50-17.00$ & $9.10-30.70$ \\
\hline
\end{tabular}

\section{Soil analyses}

Results of the geotechnical assessments performed in 2007 (D3 and D6) and 2008 (D5) are presented in (Table 1). The analysis of the soil confirmed that the burial grounds of "La Villetta" cemetery are made of sand, loam, and clay, with a very low value of permeability. As expected, interstitial oxygen was found to decrease with depth. In contrast, the bacterial concentration and the Total Organic Carbon (TOC) were found to increase with depth associated with the presence of bodies. The percentage of gravel in the D3-D6 area was found be statistically higher (average 13.95\%) than in the D5 area (average 3.10\%) $(\mathrm{P}<0.01)$. The water content between D5 and D3-D6 was found to be not significantly different ( $\mathrm{P}>0.05)$, however, in D5 it ranged between 15.60-24.80\%, while in D3-D6 it showed a more stable range between $21.20-23.10 \%$.

\section{Type of coffins}

Most of the coffins (85\%, N=287) were constructed using different wood qualities, while the remainder were made of wood with a zinc coffin insert (15\%, N=51). In all but one of the zinc-lined coffins, breaches were made through the metal in order to facilitate the decomposition process. Overall, 4 of the 5 not fully decomposed bodies were found in zinc-lined coffins which were breached, while the only body found in full adipocere status was found in a completely sealed zinc-lined coffin (Figure 2). Statistical analyses showed that the type of coffin did not influence the decomposition process $(\mathrm{P}>0.05)$, however, the presence of breaches as well as the burial time significantly influenced the decomposition process $(\mathrm{P}<0.001$ for both variables).

\section{Garments, upholsteries and artifacts}

Both coffin upholsteries and garments were found to be better preserved when made in synthetic fibers, however, these materials did not have a significant effect on the decomposition process of the bodies ( $\mathrm{P}>0.05)$. Prosthesis and dentures, if present, were always perfectly preserved.

\section{Conservative treatments}

Not observed or detected for any of the 338 bodies. 


\section{Conservation status of bodies}

Nearly all the 338 exhumed bodies (98.52\%) were found completely skeletonized. Four juvenile bodies were recovered in this exhumation and all were completely skeletonized. The youngest of the exhumed bodies (10yr), showed partial erosion of some of the smaller bones. The five bodies not completely skeletonized were all of adults reburied in 1988 and 1989. Two bodies, reburied in 1988 and 1989 respectively, were found partially skeletonized $(80 \%)$, with initial disarticulation and adipocere present in the posterior part of the lower limbs. These bodies were all placed in double coffins with breaches. Another body reburied in 1988 was found $90 \%$ skeletonized and almost completely disarticulated, but some adipocere was present in the posterior part of the body. This body was contained in a double coffin, with very large breaches. A third body reburied in 1988 was partially skeletonized (50\%), but not disarticulated, with adipocere mostly located in the posterior part of the body. This body was also contained in a single zinc coffin, with breaches. Finally, another body reburied in 1988 was all adipocere, a consequence of being contained in a double coffin, completely sealed.

\section{Stone tombs}

Cemetery "Marore"-A total of 70 bodies entombed between 1945 and 1989 were recovered from 69 stone tombs (Figures 1-3). The majority of the entombments were listed in the cemetery archive, while the unlisted body of a 2-year-old child was found together with an adult female in the same coffin. Information regarding secondary entombments were available only for a limited number of bodies and in all cases, it was unclear about the type of primary burial (e.g. inhumation or entombment). At the end of the present exhumation, of the 70 exhumed bodies, $62.85 \%(\mathrm{~N}=44)$ required reburial or cremation, due to the lack of decomposition.

\section{Personal information}

The vast majority of the bodies were adults (69 out of 70), and the cause of death was mostly natural, while a few were reported as violent (homicide, car accident, suicide). In cases of death caused by cancer, the average duration of radio- and/or chemotherapy was estimated about one year before death, according to information given by relatives present at the exhumations. A few individuals $(3.50 \%, N=5)$ showed signs of an autopsy.

\section{Location of the entombments}

The tombs were located in the northern side of the cemetery, under a concrete arcade, with virtually no exposure to the sun (Figure 2).

\section{Type of coffins}

Coffins were all double, made in wood of various quality, with a zinc coffin insert. No breaches were found to be performed on any of the coffins, even if the primary burial had been an inhumation.

\section{Garments, upholsteries and artifacts}

Both coffin upholsteries and garments were found to be better preserved when made in synthetic fibers, however, both did not have a significant effect on the decomposition process of the bodies $(\mathrm{P}>0.05)$. Prosthesis and dentures, when present, were perfectly preserved.

\section{Conservative treatments}

Not observed or detected for any of the 70 bodies.

\section{Conservation status of bodies}

Overall, of the 70 bodies exhumed, 8 (11.43\%) were found fully skeletonized and $18(25.71 \%)$ were found partially skeletonized (up to a maximum of $80 \%$ of the body, while the remainder of the body was covered in adipocere). The remaining 44 bodies $(62.85 \%)$ showed homogeneous distribution of adipocere throughout the body, mostly associated with the corification of the superficial layer of the skin. Body fluids were observed at the bottom of the vast majority of the coffins, especially in recent entombments. However, fluids were also observed in coffins that had been left in the stone tombs for up to 40 years. The body that was found to be $100 \%$ skeletonized belonged to a male deceased in 1945 , and archive information confirmed that it had been moved once after the original burial. Another body, 80\% skeletonized, was reported entombed in 1967, but exhumed and moved in 1994. With regards to the bodies of the adult female and child entombed together, they showed a similar pattern of partial skeletonization (70\%) despite the different ages and body size.

\section{Microbiology}

Aerobic and facultative anaerobic bacteria (e.g. Pasteurella pneumotropica/haemolytica) and moulds (e.g. Penicillium ss.pp. and Cladosporium ss.pp.) were observed in all the samples. No yeasts were found at either $25^{\circ} \mathrm{C}$ or $37^{\circ} \mathrm{C}$ after 11 days of incubation. Overall, the microbiological analysis did not show any significant differences in the microfauna of bodies entombed between 19 and 40 years $(\mathrm{P}>0.05)$.

\section{Discussion}

The continuous increase of the number of bodies housed in cemeteries, and the inability of cities to improve either the burial space or the number of the cemeteries, is a looming problem in many parts of the world [6,7]. Beside the practical problem, different cultures, religious practices and the general human desire to demonstrate respect for the deceased, must be taken into consideration. In Italy, the practice of so called 'body turnover' is regulated by law, with an aim to accommodate new remains, without the need to increase the cemetery area [8]. These turnover times vary whether they are inhumations or entombments and are subjected to an exhumation turnover of 10, 20 and 40 years depending on cemetery policy [8]. However, the law also states that if after the turnover time bodies are not skeletonized, they must be reburied or cremated, with a cost incurred by the families or the State.

The present study was conducted with the purpose to identify the intrinsic and extrinsic factors that affect the decomposition process of bodies buried or entombed in Parma, Italy. Thanatological taphonomical, anthropological, microbiological and geochemical 
observations and analyses were conducted on 408 bodies recovered in either individual grave pits or stone tombs. Data from this study were used to make recommendations for cemetery management and future turnover planning, with the goal of avoiding any costs, and family distress. Thanatology and taphonomy are disciplines focused on the study of the process of death [11]. While thanatology considers the phenomenon of death and the post-mortem alterations of remains [18], taphonomy is a branch of paleontology that studies the process of fossilization and follows the journey of an organism from the moment of death to its settlement in the final conservation medium $[11,13]$. Essentially, taphonomy considers all the phenomena that interplay in the process of organic matter moving from the biosphere to the lithosphere. Thanatological phenomena begins immediately after the vital functions of the human body stop [10].

Such phenomena can be divided in abiotic and transforming phenomena. Abiotic phenomena happen soon after death and are caused by the residual activity within the body, whereas transforming phenomena (e.g. skeletonization, mummification and adipocere), are strictly related with the depositional environment. Transforming phenomena may be avoided/slowed down if conservative treatments are applied to the body (e.g. mummification, embalment). Thanatology and taphonomy can be integrated with analyses of physical anthropology, archaeology, geology, microbiology and entomology, in order to obtain a complete reconstruction of the profile of the remains, the causes of death and the circumstances preceding and following the burial [11]. Furthermore, all these disciplines help clarify the decomposition process pathways of remains. When considering the 408 bodies examined in this study, there was a significant difference between the decomposition processes observed in the grave pits compared to the stone tombs. As a consequence, the two sites will be discussed separately.

\section{Grave pits}

This assessment considered the bodies post exhumation at three different burial grounds at "La Villetta" cemetery, D3-D6 performed in 2007 (384 bodies) and D5 performed in 2008 (338 bodies). While the burial soils of the three sites were similar, D5 showed a larger percentage of complete skeletonized bodies (98.50\%) compared to D3-D6 (28.20\% and 53.10\% respectively). Comparing the burial sites, the single and most important variable that has affected this outcome was the presence of stone slabs above the individual graves in D3 and D6. Gravel and sand are generally added to grave soils in order to improve drainage. The gravel, being of different dimensions, increases pore spaces available for water and air movement. However, despite the percentage of gravel in D3D6 being higher than D5, the decomposition rate was lower because of the resulting water stagnation in the soil. The presence and the weight of the slabs compacted the soil underneath, thus reducing soil pore spaces, drainage and air movement. As a consequence, the stagnation of water in cold continental climates promotes adipocere formation instead of skeletonization. As expected, there were other important factors promoting decomposition, namely burial time, the use of a single coffin and the practice of breaching the double coffins. The increase in the number and the size of the breach points were also found to have a positive effect on the decomposition process.

\section{Stone tombs}

This assessment involved 70 bodies recovered from 69 stone tombs at the "Marore" cemetery. The recovery took place in 2008 and no comparison could be conducted as there have been no previous assessments similar to this one in this or any other cemeteries. When comparing the decomposition process of these bodies with the ones recovered from the grave pits in "La Villetta" cemetery, only $11.4 \%$ bodies were found fully skeletonized and suitable to be moved to the ossuary. Most of the bodies (88.6\%) required either a second/third burial or to undergo cremation. Such bodies showed a homogenous distribution of adipocere. This study was contrary to Mant (1957) who stated that coffins speed up the decomposition process by accelerating the postmortem dissolution of the body when compared to corpses buried directly into soil. This is possibly due to the fact that in the present study all coffins were found intact (not broken or breached), while Mant refers to coffins with collapsed lids, gaps around the seals and explosions due to the pressure build up within [19].

In such conditions, the bodies were therefore exposed to the environment for part of their entombment period, allowing a faster decomposition process. Overall, for bodies exhumed from stone tombs, the factor that was found to have played the most significant role in the decomposition process was the second/third entombment. In fact, of the bodies found skeletonized, between 80 and 100 had undergone a process of entombment and exhumation twice before the exhumation described in this study. During this process bodies may be exposed to the environment for up to several days. When the coffin is opened for assessment the body is exposed to air and possibly carrion insects $[20,21]$. The result of such a sudden change in the environment to which the body is exposed may promote a change in the decomposition process. Clothing may have played a role in the promotion of the formation of adipocere in the stone tombs. However, only a few studies have been published alluding to the fact that clothing may facilitate the formation of adipocere, but those studies were performed exclusively on bodies buried directly into soil [19,22].

Clothing are able to absorb and retain the moisture of the soil and body decomposition fluids, and this may promote the formation of adipocere in either inhumed or entombed bodies. The prelimary microbiological analyses showed that samples of soft tissues taken from bodies at the same stage of decomposition but entombed for a different amount of time (from 40 to 19 years) have a similar microbiological profile. The results indicate that when a body is entombed in a sealed double coffin (wood and zinc), the environment surrounding the body remains chemically and (micro) biologically stable for decades. As a consequence, the decomposition of the body is mostly prevented, and turned into adipocere. Other studies based on solid lead coffins have shown 
a different result, whereby the lead present in the coffin poisons the microorganisms preventing decomposition occurring past the initial autolysis stage [23].

In conclusion, to improve the management of body turnover in cemeteries located in continental climates like Parma, it is recommended to limit the number of entombments and increase inhumations in burial grounds without slabs. The overall preference is cremation. Burial grounds should have sand and gravel added at burial to improve the soil structure and permeability. Another factor that clearly promotes the decomposition process is the presence of multiple breach points in double coffins, however, with the present law, those are only allowed in between the first and the second inhumation.

\section{Acknowledgement}

The Authors would like to thank Alberto Barattini, Brendan Chapman, Marco Ghirardi, Gabriele Righi and Laura Zerbini for their valuable inputs to improve the manuscript.

\section{Conflict of Interest}

No conflict of interest.

\section{References}

1. Rakita GFM, Buikstra J, Beck LA, Wiiliams SR (2006) Interacting with the dead: perspectives on mortuary archaeology for the new millennium. University Press of Florida 16(3): 276-277.

2. Bass W, Jefferson J (2004) Death's acre-Inside the legendary forensic lab. In: The Body Farm: where the dead do tell tales New York: Berkley Books, New York, USA

3. AAVV (2008) Cremazione: Italia divisa in due. Corriere della Sera. P: 8-9.

4. AAVV (2016) International cremation statistics. The Cremation Society of Great Britain, UK.

5. AAVV (2015) Italia: cremazioni al 20\% nel 2014. So Crem, Società di Cremazione Bologna, Italy.

6. Ryan K (2017) Housing the dead: what happens when a city runs out of space? The Conversation
7. Mc Manus J (2015) The world is running out of burial space. BBC News

8. AAVV (1990) Regolamento di Polizia Mortuaria. Gazzetta Ufficiale della Repubblica Italiana, Italy, pp: 1-285.

9. Brothwell DR (1981) Digging up bones: the excavation, treatment, and study of human skeletal remains Cornell University Press, USA.

10. Puccini C (1995) Istituzioni di medicina legale. In: Casa Editrice Ambrosiana, Milano, Italy.

11. Haglund WD, Sorg M (1997) Forensic taphonomy: the postmortem fate of human remains CRC Press, USA.

12. Vass AA, Barshick SA, Sega G, Caton J, Love JC, et al. (2002) Decomposition chemistry of human remains: a new methodology for determining the postmortem interval. J Forensic Sci 47(3): 542-553.

13. Haglund WD, Sorg M (2002) Advances in forensic taphonomy (method, theory and archaeological perspectives): CRC Press, USA.

14. Hill AP (1990) Taphonomy of contemporary and late venozoic East African vertebrates. In: University of London, London.

15. Grayson D (1984) Quantitative zooarchaeology topics in the analysis of archaeological faunas. (1 $1^{\text {st }}$ edn.), Academic Press, USA.

16. AAVV (2003) Decreto legislativo 30 giugno 2003 "Codice in materia di protezione dei dati personali". Gazzetta Ufficiale della Repubblica Italiana, Italy, pp: 1-196.

17. AAVV (2016) General Data Protection Regulation. Regulation 2016/679. European Union, Europe.

18. Canuto G, Tovo S (1996) Medicina legale e delle assicurazioni. (12 edn.), Piccin, Padova, Italy.

19. Mant AK, Furbank R (1957) Adipocere: a review. J Forensic Med 4: 1835.

20. Haskell NH, Williams RE (2009) Entomology \& Death: A Procedural Guide. In: (2 ${ }^{\text {nd }}$ edn.), Forensic Entomology Partners, Clemenson, SC, USA.

21. Byrd JH, Castner JL (2010) Forensic Entomology-The utility of arthropods in legal investigation. ( $2^{\text {nd }}$ edn.), CRC Press, Boca Raton, FL, USA.

22. Mellen PFM, Lowry MA, Micozzi MS (1993) Experimental observations on adipocere formation. J Forensic Sci 38(1): 91-93.

23. Vass AA (2001) Beyond the grave-understanding human decomposition. Microbiol Today (28): 190-192. 